\title{
Curious Case of Bactericidal Action of ZnO
}

\author{
Somnath Ghosh, ${ }^{1,2}$ R. Gowri Sankar, ${ }^{2}$ and V. Vandana ${ }^{2}$ \\ ${ }^{1}$ Solid State and Structural Chemistry Unit (SSCU), Indian Institute of Science (IISc), Bangalore 560012, India \\ ${ }^{2}$ Department of Chemistry, Central Research Laboratory, Gandhi Institute of Technology and Management (GITAM) University, \\ Rushikonda, Visakhapatnam, Andhra Pradesh 530045, India
}

Correspondence should be addressed to Somnath Ghosh; ghoshmnth@gmail.com

Received 1 July 2014; Revised 19 September 2014; Accepted 3 October 2014; Published 17 November 2014

Academic Editor: Irshad Hussain

Copyright (C) 2014 Somnath Ghosh et al. This is an open access article distributed under the Creative Commons Attribution License, which permits unrestricted use, distribution, and reproduction in any medium, provided the original work is properly cited.

\begin{abstract}
$\mathrm{ZnO}$ nanoparticles (NPs) are well known for their bactericidal properties. Various mechanisms are proposed for their bactericidal activity. An ambiguity still prevails to know which mechanism or property is mainly influencing the bactericidal activity of $\mathrm{ZnO}$ NPs. The antibacterial properties of ZnO NPs were investigated against both Gram-positive and Gram-negative bacteria. Different $\mathrm{ZnO}$ samples with different degrees of surface oxygen vacancies were prepared from $\mathrm{ZnO}_{2}$. The surface oxygen vacancy and thereby reactive oxygen species (ROS) production in aqueous $\mathrm{ZnO}$ solution are quantified by photoluminescence (PL) and electron paramagnetic resonance (EPR) spin trapping experiments, respectively. Systematic experiments have been performed to validate a precise antibacterial mechanism of $\mathrm{ZnO}$ particle.
\end{abstract}

\section{Introduction}

The rapid development of nanotechnology emerges in a diverse range of nanomaterials and nanoproducts [1]. Various desired targets have been accomplished in order to employ materials in medicinal fields by maneuvering them at their atomic size scale $[2,3]$ through nanotechnology. Unfortunately, many such benevolent materials develop toxicity. As toxicities are selective to biological systems, nanomaterials are well exploited for antibacterial applications. To combat bacterial infections metal and metal oxide NPs in various forms are well studied [4-15].

The exposure of such NPs in the environment demands a fundamental understanding about their mode and range of toxicity. Their mode or modes of action towards bacteria remained ambiguous.

$\mathrm{ZnO}$ NPs have been extensively used as antibacterial agents for water purification [16-19], biofilm prevention [20$22]$, sunscreen lotion [23, 24], wound dressing [25], and so forth. Protection against intestinal bacterial infections by bulk $\mathrm{ZnO}$ was reported in late 1990s [26, 27] though its bactericidal activity against a broad spectrum of bacteria (e.g., Staphylococcus aureus, Escherichia coli, Bacillus subtilis, Streptococcus agalactiae, etc.) was revealed little late when $\mathrm{ZnO}$
NPs were exposed to bacterial solution [28-32]. Although the antimicrobial properties of $\mathrm{ZnO} N \mathrm{~N}$ s have been utilized to kill bacteria in different issues, their mechanistic pathways are still imprecise. The mechanisms of antibacterial property of $\mathrm{ZnO}$ NPs so far proposed are as follows: (i) physical attack of ZnO NPs on the bacteria $[18,33,34]$ (ZnO NPs can adhere to the bacterial cell wall surface and eventually pierce into cell leading to bacterial death by membrane disruption), (ii) oxidative stress generated by particles in solutions $[35,36]$ (hydroxyl radials are the result of interaction of $\mathrm{ZnO}$ NPs with aqueous solution which causes oxidation of bacterial metabolic enzyme leading to bacterial death), and (iii) solubility of NPs in aqueous solution [37,38]. But none of them is solely responsible on a "one fits all" basis for the desired activity as reported in the literature. The above-mentioned different mechanisms play a role in the bactericidal activity because of size, surface oxygen vacancy, and active surface area of the $\mathrm{ZnO}$ particles. A careful investigation is required to evaluate the influence of each such property towards the toxicity of bacteria.

The antibacterial properties of $\mathrm{ZnO}$ NPs were investigated against both Gram-positive and Gram-negative bacteria. During bactericidal activity study various properties (e.g., particle size, solubility, surface area, etc.) of $\mathrm{ZnO}$ samples 
were maintained unaltered when varying the other (e.g., reactive oxygen species (ROS) production, surface defect) through simple chemical route to correlate the antibacterial activity of $\mathrm{ZnO}$ with such property. Similarly, when solubility of $\mathrm{ZnO}$ samples was varied, ROS production was arrested by glutathione (GSH) in order to eliminate or establish the possibility of oxidative stress mechanism for their bactericidal action. These systematic studies state that bactericidal efficiency of $\mathrm{ZnO}$ is little higher for Grampositive Staphylococcus aureus ATCC 25923 compared to Gram-negative Escherichia coli MTCC 1302. It has been found that as the surface area increases the solubility of the same sized different $\mathrm{ZnO}$ samples in saline water increases and also the bactericidal activity. Interestingly, when ROS production was stopped by employing GSH, bactericidal activity for each of the samples decreases a little. When the amount of ROS production was raised by creating more surface defects in $\mathrm{ZnO}$ samples maintaining the same solubility, the bactericidal activity increases with the rise in ROS production. Surprisingly for these samples when ROS production in aqueous solution was blocked bactericidal activity decreases compared to when ROS production was not arrested. But level of antibacterial activity prevails similarly within those samples after ROS production was blocked. The whole understanding of all the observations says that each of these individual physicochemical properties of $\mathrm{ZnO}$ samples contributes individually towards the killing of bacteria and noticeably the contribution by ROS production due to surface defect in account of bactericidal activity is the leading part.

\section{Experimental Section}

2.1. Materials. Zinc acetate dihydrate (S D Fine-Chem Pvt. Ltd., India), diethylene glycol (Merck, India), hydrogen peroxide $(30 \%, S$ D Fine-Chem Pvt. Ltd., India), $2^{\prime}, 7^{\prime}$-dichlorofluorescein diacetate (DCFH-DA), glutathione (GSH), 5,5-dimethyl-1-pyrroline-N-oxide (DMPO) (Sigma Aldrich Chemical Co. Inc., Germany), and nutrient broth (Hi-Media Laboratories Ltd., India) were used as such without further purification. Escherichia coli MTCC 1302 and Staphylococcus aureus ATCC 25923 (M.S. Ramaiah Hospital, Bangalore) were used for the bacterial studies.

2.2. Synthesis of $\mathrm{ZnO}$ Submicron Particles. Zinc acetate dihydrate $(0.9855 \mathrm{gm})$ was added to $45 \mathrm{~mL}$ of diethylene glycol (DEG) with vigorous stirring for $0.5 \mathrm{~h}$ at room temperature. The mixture was refluxed at $180^{\circ} \mathrm{C}$ for $1 \mathrm{~h}$, similar to the procedure described by Ghosh et al. [18]. A milky white precipitate appeared at the end of the reaction indicating the formation of $\mathrm{ZnO}$. The obtained milky precipitate was centrifuged, separated, and washed with ethanol several times by repeated sonication-centrifugation process. The precipitate so obtained was dried under vacuum at $60^{\circ} \mathrm{C}$ for $6 \mathrm{~h}$ and characterized by powder X-ray diffraction.

2.3. Synthesis of $\mathrm{ZnO}_{2}$. The pristine $\mathrm{ZnO}$ powder was stirred with $30 \mathrm{~mL}$ of aqueous $\mathrm{KOH}(1 \mathrm{M})$ solution for $2 \mathrm{~h}$ at room temperature and the solution was then washed with water and $50 \mathrm{~mL}$ of $\mathrm{H}_{2} \mathrm{O}_{2}(30 \%)$ was added, and stirring continued for $24 \mathrm{~h}$ at $45^{\circ} \mathrm{C}$. The precipitate was washed with water and dried under vacuum and characterized by powder X-ray diffraction, thermogravimetric study.

2.4. Synthesis of Various $\mathrm{ZnO}$ Samples from $\mathrm{ZnO}_{2}$. The obtained $\mathrm{ZnO}_{2}$ was heated at $230^{\circ} \mathrm{C}$ in air and also at $300^{\circ} \mathrm{C}$, $400^{\circ} \mathrm{C}$, and $500^{\circ} \mathrm{C}$ under $\mathrm{H}_{2}\left(5 \% \mathrm{H}_{2}\right.$ and $\left.95 \% \mathrm{Ar}\right)$ atmosphere (flow rate $10 \mathrm{~mL} / \mathrm{min}$ ) for $3 \mathrm{~h}$. Heated samples were designated as $\mathrm{ZnO}-\mathrm{H}, \mathrm{ZnO}-300, \mathrm{ZnO}-400$, and $\mathrm{ZnO}-500$, respectively, and characterized by powder X-ray diffraction.

2.5. DCFH-DA Test. A fluorescence experiment was carried out using a sensitive probe, $2^{\prime}, 7^{\prime}$-dichlorofluorescein diacetate (DCFH-DA), for the detection of ROS by incubating the samples in $30 \mathrm{~mL}$ of $0.05 \times 10^{-3} \mathrm{M}$ DCFH-DA solution for $2 \mathrm{~h}$. The colourless DCFH-DA solution changes to green upon exposure with samples and imparts a fluorescence peak at $\sim 525 \mathrm{~nm}$ (excited at $485 \mathrm{~nm}$ ) which indicates the samples produced ROS in aqueous solution.

2.6. Suppression of ROS Production from Aqueous $\mathrm{ZnO}$ by GSH Treatment. Glutathione ( $\gamma$-glutamylcysteinylglycine, GSH), a sulfhydryl (-SH) antioxidant, an antitoxin, is sued for the suppression of $\mathrm{ROS}$ as produced from aqueous $\mathrm{ZnO}$ solution. Being water soluble and having facile electron donating power, GSH first arrests ROS (i.e., hydroxyl radical, $\mathrm{OH}^{\bullet}$ ) by reducing them. Various aqueous $\mathrm{ZnO}$ samples were incubated with excess GSH till the solution became colorless and hence nonfluorescent (i.e., no peak at $\sim 525 \mathrm{~nm}$ when excited at $485 \mathrm{~nm}$ ).

2.7. Minimum Inhibition Concentration (MIC). The MIC is the lowest concentration at which a material exhibits antimicrobial activity and this was done by serial dilution techniques. Sterile test tubes were taken separately with $9.9 \mathrm{~mL}$ of saline water, inoculated with corresponding microorganisms (fresh culture, mid-log phase, OD600 0.045-0.050), and diluted up to $10^{8} \mathrm{CFU} \mathrm{mL}^{-1}$. Different concentrations (5$200 \mu \mathrm{g} \mathrm{mL}^{-1}$ ) of various $\mathrm{ZnO}$ samples were added to individual test tubes. After $4 \mathrm{~h}$ incubation at $37^{\circ} \mathrm{C}$, each $0.1 \mathrm{~mL}$ of this solution was taken and plated in sterile nutrient agar plates and the plates were incubated at $37^{\circ} \mathrm{C}$ overnight and colonies were counted to determine the MIC.

\section{Instrumentation and Characterization}

3.1. Powder X-Ray Diffraction (XRD). Powder XRD patterns of the prepared $\mathrm{ZnO}$ were recorded on Philips XRD "X" PERT $\mathrm{PRO}$ diffractometer using $\mathrm{Cu}-\mathrm{K} \alpha$ radiation $(\lambda=1.5438 \AA)$ as $\mathrm{X}$-ray source.

3.2. Inductively Coupled Plasma-Optical Emission Spectrophotometry (ICPOES). The amount of $\mathrm{ZnO}$ dissolved in known volume of saline water for different samples was estimated using Perkin-Elmer optima 2100 ICPOES at $\lambda=213.8 \mathrm{~nm}$. 


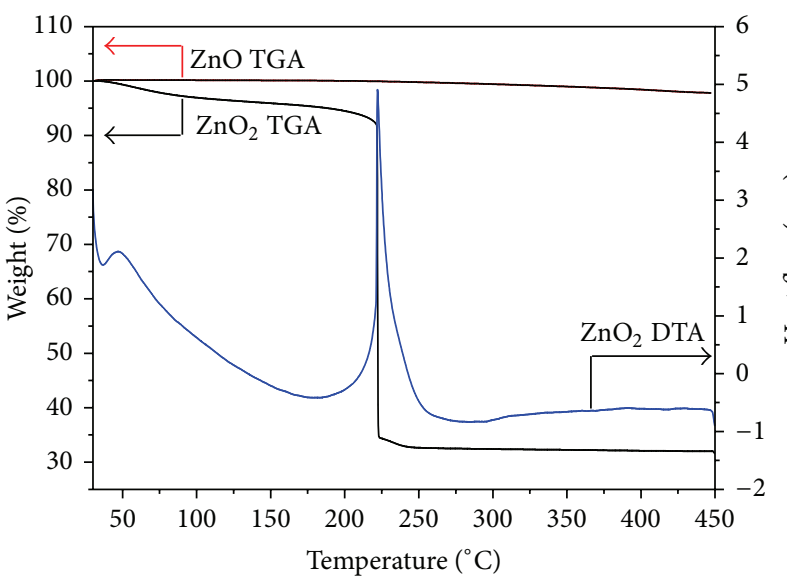

(a)

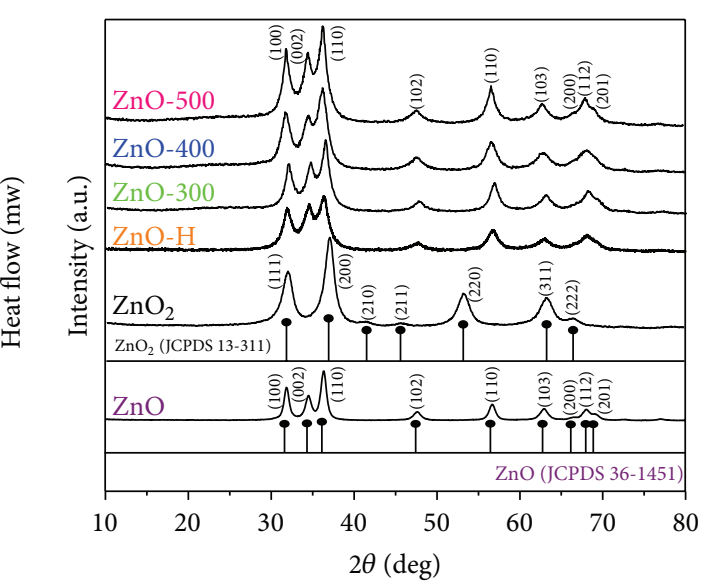

(b)

Figure 1: (a) TGA (black) and DTA (blue) plot of $\mathrm{ZnO}_{2}$; (b) $\mathrm{XRD}$ of $\mathrm{ZnO}_{2}$ and different $\mathrm{ZnO}$ samples.

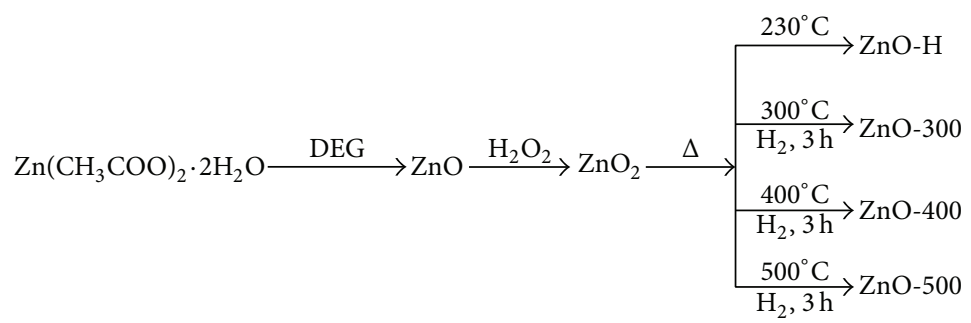

SCHEME 1: Flow chart of conversion of $\mathrm{ZnO}$ to $\mathrm{ZnO}_{2}$ and again to different $\mathrm{ZnO}$ samples.

3.3. BET Surface Area. Surface area of different samples was determined by NOVA surface area analyzer.

3.4. Scanning Electron Microscopy (SEM). The morphological studies of the prepared $\mathrm{ZnO}$ were carried out in field emission scanning electron microscope (FE-SEM SIRION). A drop of well-dispersed particles in water was cast onto a piece of silicon wafer and air-dried. A thin gold coating was applied to avoid charging during scanning and a detailed microscopic study was carried out.

3.5. Electron Paramagnetic Resonance Spectroscopy (EPR). Hydroxyl radicals were detected by EPR-spin trapping technique using spin trapper 5,5-dimethyl-1-pyrroline-N-oxide (DMPO, 0.02 M). Aqueous suspensions of different $\mathrm{ZnO}$ samples were drawn separately into quartz capillaries (one end closed) along with DMPO. The capillaries were placed in the EPR tube and spectra were recorded on a Bruker emx $\mathrm{X}$-band EPR spectrometer.

3.6. Photoluminescence (PL) Study. PL spectra were recorded in Jobin Yvon FluoroLog 4 (Horiba) by exciting each equally concentrated $\mathrm{ZnO}$ sample solution (aq.) at $370 \mathrm{~nm}$.

3.7. Thermogravimetric Study. Thermogravimetric studies were done in thermogravimetric system (Cahn TG131).

\section{Results and Discussion}

In order to elucidate proper mechanism of antibacterial activity, $\mathrm{ZnO}$ samples with different degrees of physicochemical properties have been synthesized through a simple route as depicted in Scheme 1. Submicron size $\mathrm{ZnO}$ particles were synthesized by polyol method. The as-synthesized $\mathrm{ZnO}$ particles were converted to $\mathrm{ZnO}_{2}$ by reacting with $\mathrm{H}_{2} \mathrm{O}_{2}$ and heated in presence of $\mathrm{H}_{2}$ gas at different temperatures.

In this method, various degrees of surface defects (oxygen vacancies) were obtained without much change in particle nature between the samples. The thermogravimetric analysis (TGA) and differential thermal analysis (DTA) of $\mathrm{ZnO}_{2}$ show a sharp exothermic peak (Figure 1(a)), indicating decomposition of $\mathrm{ZnO}_{2}$ to $\mathrm{ZnO}$ at $\sim 225^{\circ} \mathrm{C}$ and the reactions were carried out above this temperature.

XRD patterns were obtained for all the samples and are depicted in Figure 1(b). All the reflections were assigned with standard wurtzite structure of $\mathrm{ZnO}$ (JCPDS file number 36-1451) while for $\mathrm{ZnO}_{2}$ the peaks are assigned with pure cubic phase of $\mathrm{ZnO}_{2}$ (JCPDS file number 13-311). SEM pictures obtained for the samples along with $\mathrm{ZnO}_{2}$ are shown in Figure 2. It reveals that the pristine $\mathrm{ZnO}$ particles are spherical and the size varies between 150 and $250 \mathrm{~nm}$ (Figure 2(a)). On treatment with $\mathrm{H}_{2} \mathrm{O}_{2}$, few smaller sized particles disintegrated (Figure 2(b)) and the larger particles (size 150-250 $\mathrm{nm}$ ) remain intact even after heating at different temperatures (Figures 2(c), 2(d), 2(e), and 2(f)). 


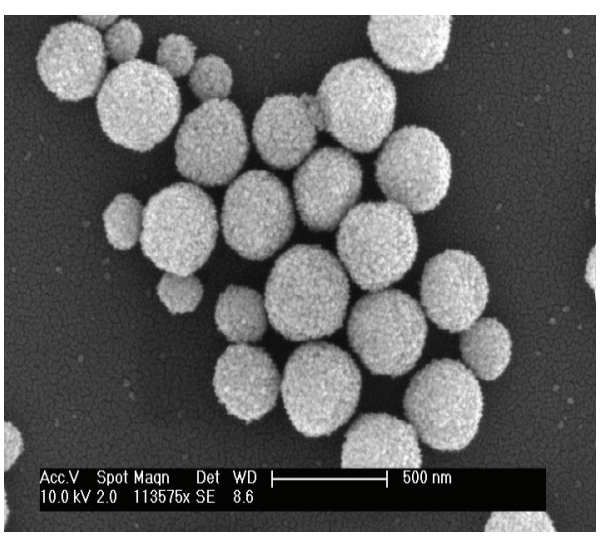

(a)

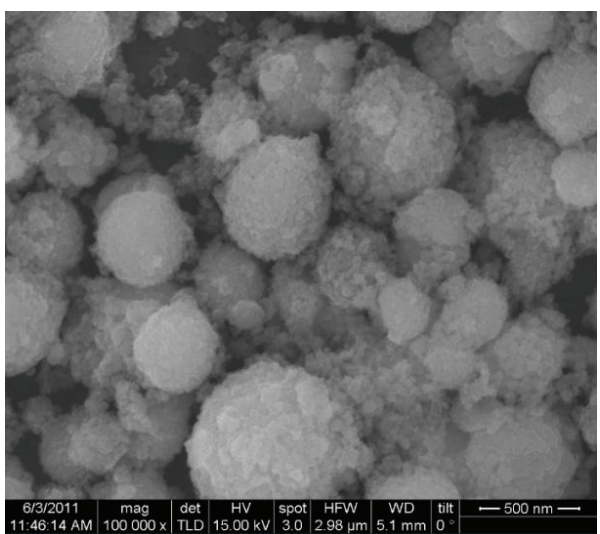

(c)

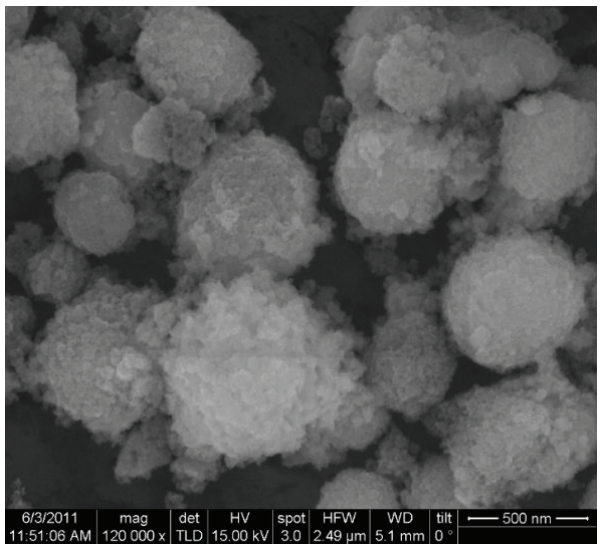

(e)

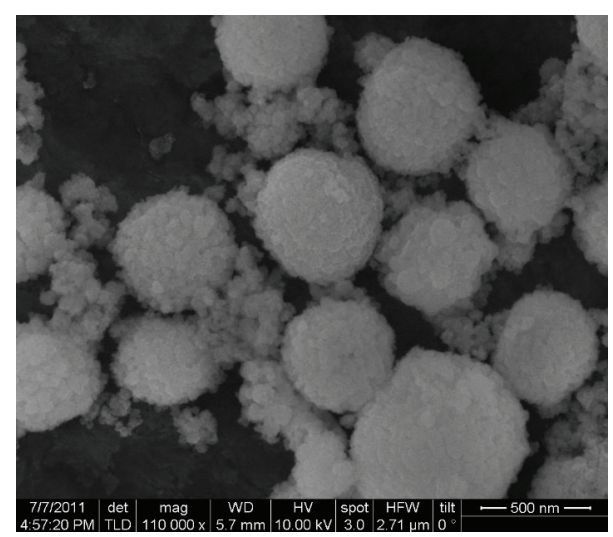

(b)

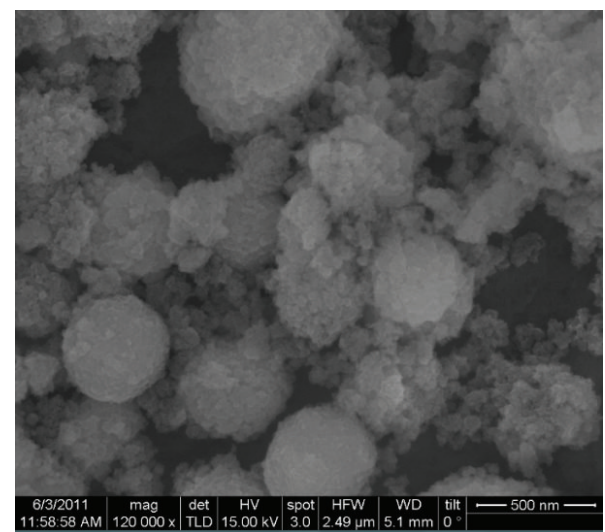

(d)

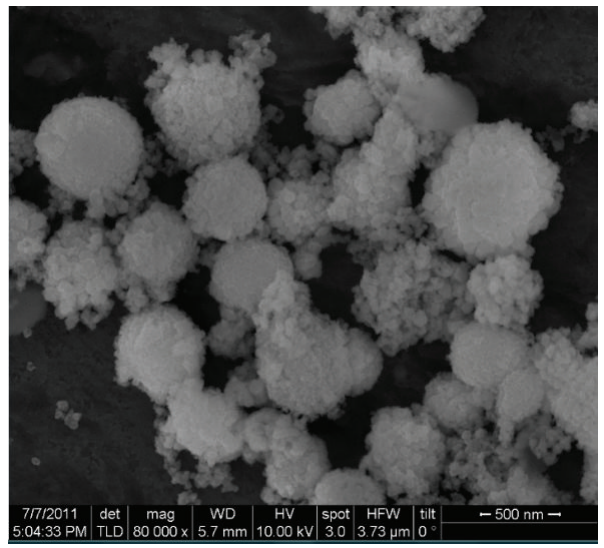

(f)

Figure 2: SEM micrographs of (a) $\mathrm{ZnO}$, (b) $\mathrm{ZnO}_{2}$, (c) $\mathrm{ZnO}-\mathrm{H}$, (d) ZnO-300, (e) ZnO-400, and (f) ZnO-500 (all scale bars: 500 nm).

The physicochemical properties of $\mathrm{ZnO}$ samples were tabulated along with MICs as shown in Table 1. To investigate the mechanism of antibacterial activity, MICs were determined with and without treating $\mathrm{ZnO}$ samples with GSH.

From pristine $\mathrm{ZnO}$ to $\mathrm{ZnO}-\mathrm{H}$, the surface area and solubility increase which may be attributed to the smaller fragmentation on treatment with $\mathrm{H}_{2} \mathrm{O}_{2}$ and heating, but both solubility and surface area remain unaltered for other samples of $\mathrm{ZnO}-300$ to $\mathrm{ZnO}-500$ (Figure 3(a) and Table 1).
When bactericidal activity was evaluated without GSH treatment, MICs for $\mathrm{ZnO}$ to $\mathrm{ZnO}-500$ decrease (Table 1 and Figure 3(b)). The surface area (and hence solubility) of $\mathrm{ZnO}$ to $\mathrm{ZnO}-\mathrm{H}$ increases, but EPR peak-area due to ROS production does not differ much. Bactericidal activity of $\mathrm{ZnO}$ NPs increases along with increase in solubility reported earlier [37, 38]. Thus, the decrease in MIC for $\mathrm{ZnO}$ to $\mathrm{ZnO}$ $\mathrm{H}$ could be accounted by the solubility factor. But the same argument does not fit to account the MIC values of $\mathrm{ZnO}-300$ 


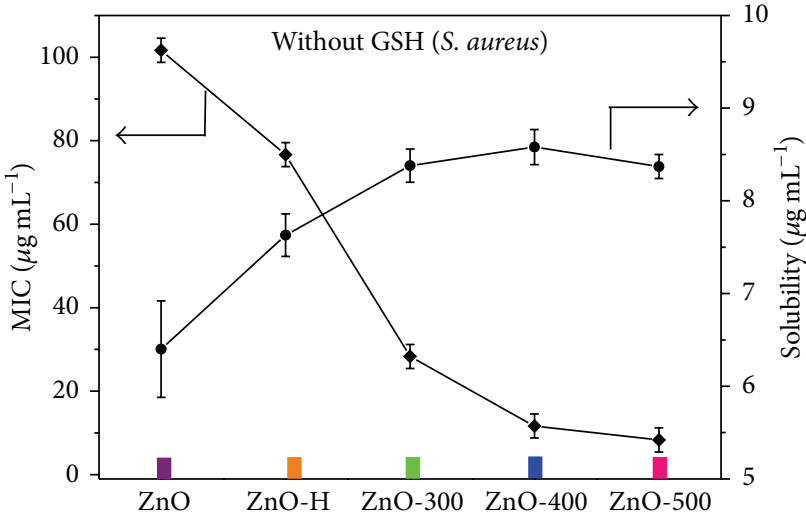

(a)

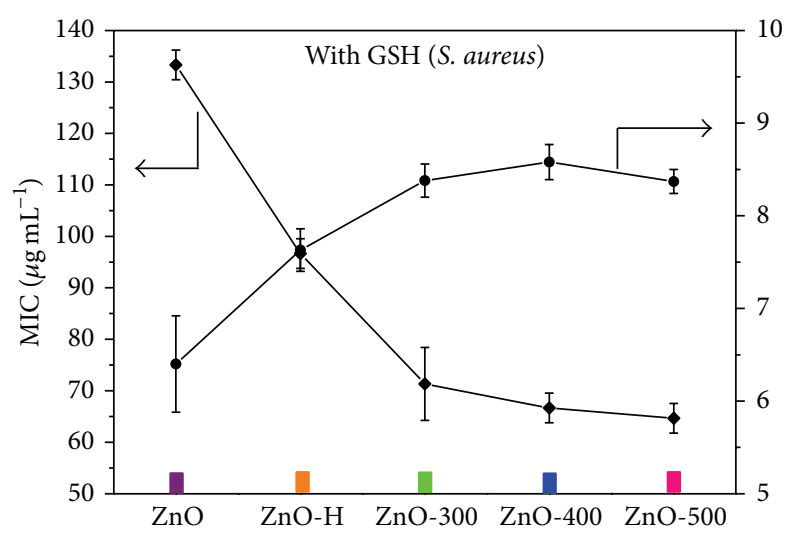

(c)

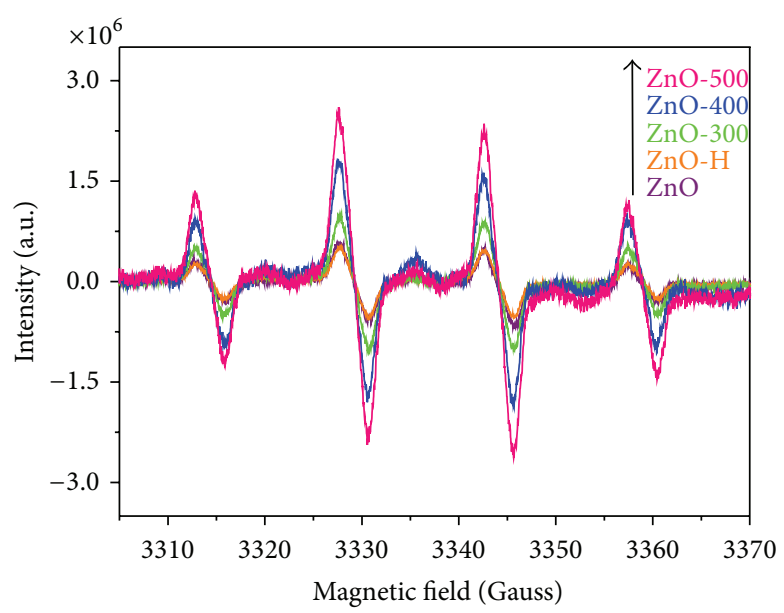

(e)

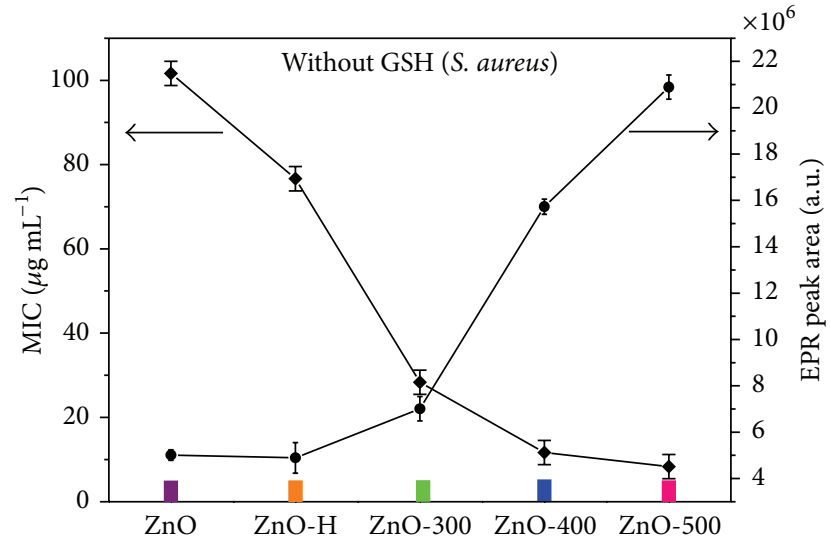

(b)

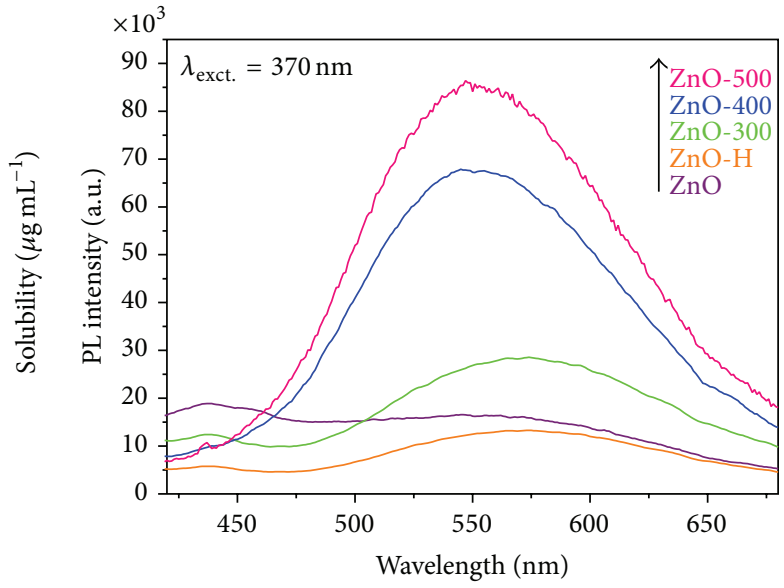

(d)

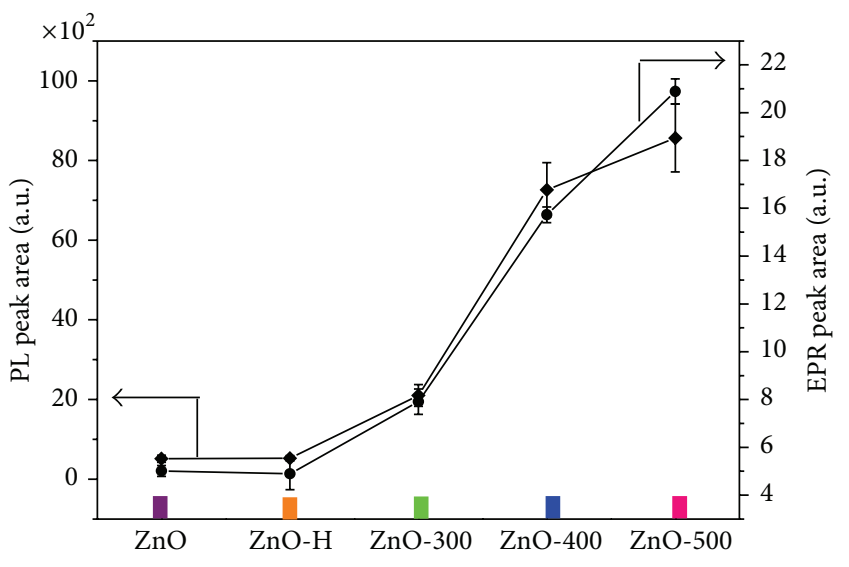

(f)

FIGURE 3: Plots of (a) MICs (without GSH) versus solubility, (b) MICs (without GSH) versus EPR peak area, and (c) MICs (with GSH) versus solubility; (d) PL spectra; (e) EPR spectra; and (f) correlation plot of EPR peak area versus PL peak area of different ZnO samples.

to $\mathrm{ZnO}-500$. Solubility (Table 1 ) of $\mathrm{ZnO}-300$ to $\mathrm{ZnO}-500$ in saline was the same, but MIC value decreases or bactericidal activity increases from $\mathrm{ZnO}-300$ to $\mathrm{ZnO}-500$. So not only the solubility of $\mathrm{ZnO}$ samples but also the other factors are responsible for its bactericidal activity.
Similarly, when bactericidal activity was determined after GSH (i.e., without ROS production) treatment with $\mathrm{ZnO}$ samples, MIC values (Table 1; Figure 3(c)) for $\mathrm{ZnO}-300$ to $\mathrm{ZnO}-500$ were almost the same indicating oxidative stress due to the fact that ROS is the governing factor as other 
TABLE 1: Different physicochemical properties and minimum inhibition concentration (MIC) values.

\begin{tabular}{|c|c|c|c|c|c|c|c|}
\hline \multirow[t]{2}{*}{ Materials } & \multirow{2}{*}{$\begin{array}{c}\text { Surface area } \\
\qquad\left(\mathrm{m}^{2} / \mathrm{g}\right)\end{array}$} & \multirow[t]{2}{*}{ Solubility $\left(\mu \mathrm{g} \mathrm{mL} L^{-1}\right)$} & \multirow{2}{*}{$\begin{array}{l}\text { EPR peak area } \\
\quad\left(\text { a.u. } \times 10^{6}\right)\end{array}$} & \multicolumn{2}{|c|}{$\begin{array}{c}\text { S. aureus } \\
\text { MIC }\left(\mu \mathrm{g} \mathrm{mL}^{-1}\right)\end{array}$} & \multicolumn{2}{|c|}{$\begin{array}{c}\text { E. coli } \\
\operatorname{MIC}\left(\mu \mathrm{g} \mathrm{mL}^{-1}\right)\end{array}$} \\
\hline & & & & Without GSH & With GSH & Without GSH & With GSH \\
\hline $\mathrm{ZnO}$ & $23.81 \pm 0.23$ & $6.40 \pm 0.52$ & $05.01 \pm 0.23$ & $101.66 \pm 2.88$ & $133.33 \pm 2.88$ & $125.00 \pm 5.00$ & $168.33 \pm 2.88$ \\
\hline $\mathrm{ZnO}-\mathrm{H}$ & $37.51 \pm 0.16$ & $7.63 \pm 0.23$ & $04.89 \pm 0.66$ & $76.66 \pm 2.88$ & $96.66 \pm 2.88$ & $96.66 \pm 2.88$ & $91.66 \pm 2.88$ \\
\hline $\mathrm{ZnO}-300$ & $41.84 \pm 0.89$ & $8.38 \pm 0.18$ & $07.91 \pm 0.53$ & $28.33 \pm 2.88$ & $71.33 \pm 7.09$ & $43.33 \pm 2.88$ & $88.33 \pm 2.88$ \\
\hline $\mathrm{ZnO}-400$ & $40.23 \pm 0.57$ & $8.58 \pm 0.15$ & $15.73 \pm 0.33$ & $11.66 \pm 2.88$ & $66.66 \pm 2.88$ & $26.66 \pm 2.88$ & $98.33 \pm 2.88$ \\
\hline $\mathrm{ZnO}-500$ & $41.39 \pm 0.63$ & $8.37 \pm 0.13$ & $20.89 \pm 0.52$ & $8.33 \pm 2.88$ & $61.66 \pm 2.88$ & $13.33 \pm 2.88$ & $101.66 \pm 2.88$ \\
\hline
\end{tabular}

factors like solubility and particle size remain unchanged for $\mathrm{ZnO}$ samples. The mechanism by which ROS (i.e., $\mathrm{OH}^{\bullet}$ ) formed on the $\mathrm{ZnO}$ surface is not clear, although some investigations on the nature of the $\mathrm{ZnO}$ surface such as chemisorbed $\mathrm{OH}$ species after interaction with water produces ROS have been reported [39].

In addition, a little is known about the nature of defect sites on a wet metal oxide surface. The formation of ROS may be explained by assuming the formation of hydroxyl radicals by the reaction of water and (dissolved) oxygen over basic metal oxides [40]:

$$
\begin{gathered}
\frac{1}{2} \mathrm{O}_{2} \longleftrightarrow \mathrm{O}_{\mathrm{s}} \\
2 \mathrm{H}_{2} \mathrm{O}+2 \mathrm{O}_{\mathrm{s}}^{-} \longleftrightarrow 2 \mathrm{OH}^{-}+2 \mathrm{OH}_{\mathrm{s}}^{-} \\
2 \mathrm{OH}_{\mathrm{s}}^{-} \longleftrightarrow \mathrm{H}_{2} \mathrm{O}+\mathrm{V}_{\mathrm{O}}+\mathrm{O}_{\mathrm{s}}{ }^{2-} \\
\mathrm{O}_{\mathrm{s}}+\mathrm{V}_{\mathrm{O}}+\mathrm{O}_{\mathrm{s}}{ }^{2-} \longleftrightarrow 2 \mathrm{O}_{\mathrm{s}}^{-}
\end{gathered}
$$

The net reaction is $\frac{1}{2} \mathrm{O}_{2}+\mathrm{H}_{2} \mathrm{O} \longleftrightarrow 2 \mathrm{OH}^{\circ}$

where $V_{O}$ refers to an oxygen vacancy and " $s$ " refers to surface species.

The higher oxygen vacancy, the higher ROS production. This is further shown in the PL spectra of the samples (Figure 3(d)). The green emission between 440 and $700 \mathrm{~nm}$ is due to surface oxygen vacancy. The increase in PL peak area (Figure 3(e)) starting from $\mathrm{ZnO}$ to $\mathrm{ZnO}-500$ indicates the increase in oxygen vacancy [41]. When such areas are plotted against the corresponding $\mathrm{ZnO}$ samples, this shows almost a linear increase and the shape of the curve matches well with the EPR peak area as shown in Figure 3(f). This supports the above proposed mechanism for the ROS production through oxygen vacancy of $\mathrm{ZnO}$.

\section{Conclusions}

The method adopted for the synthesis of $\mathrm{ZnO}$ and $\mathrm{ZnO}_{2}$ is very simple and effective. Different physicochemical properties of $\mathrm{ZnO}$ have been varied to validate their influencing nature towards their bactericidal action. When oxidative stress has been nullified by arresting $\mathrm{OH}^{\bullet}$ (hydroxyl) radical with GSH, MICs of $\mathrm{ZnO}$ samples (from $\mathrm{ZnO}$ to $\mathrm{ZnO}-\mathrm{H}$ ) decrease with the increase of their surface area (particle size remains the same) and solubility. The effect of oxidative stress towards bactericidal action has been considered (i.e., without GSH treatment) and the MICs of $\mathrm{ZnO}$ samples decrease with the increase of the surface defects or ROS production (from $\mathrm{ZnO}-300$ to $\mathrm{ZnO}-500$ ). Throughout the experiments, particles sizes of $\mathrm{ZnO}$ samples were constant and the effect due to physical attack (i.e., direct interactions between the particles and bacteria) is the same and cannot be avoided. Bactericidal properties of $\mathrm{ZnO}$ are due to the combination of all depicted mechanisms. It can be concluded that out of all mechanisms oxidative stress developed in bacteria through ROS production of $\mathrm{ZnO}$ samples is the most influencing factor for its bactericidal activity.

\section{Conflict of Interests}

The authors declare that there is no conflict of interests regarding the publication of this paper.

\section{Acknowledgments}

The authors thank Nano Centre (IISc, Bangalore) for electron microscope and XRD facility. The authors are indebted to Dr. H. N. Vasan for his valuable scientific suggestions.

\section{References}

[1] V. Biju, "Chemical modifications and bioconjugate reactions of nanomaterials for sensing, imaging, drug delivery and therapy," Chemical Society Reviews, vol. 43, no. 3, pp. 744-764, 2014.

[2] K. M. L. Taylor-Pashow, J. Della Rocca, R. C. Huxford, and W. Lin, "Hybrid nanomaterials for biomedical applications," Chemical Communications, vol. 46, no. 32, pp. 5832-5849, 2010.

[3] S. Ghosh, R. Kaushik, K. Nagalakshmi et al., "Antimicrobial activity of highly stable silver nanoparticles embedded in agaragar matrix as a thin film," Carbohydrate Research, vol. 345, no. 15, pp. 2220-2227, 2010.

[4] S. Ghosh, A. Saraswathi, S. S. Indi, S. L. Hoti, and H. N. Vasan, “Ag@AgI, core@shell structure in agarose matrix as hybrid: synthesis, characterization, and antimicrobial activity," Langmuir, vol. 28, no. 22, pp. 8550-8561, 2012.

[5] N. Gao, Y. Chen, and J. Jiang, " $\mathrm{Ag} @ \mathrm{Fe}_{2} \mathrm{O}_{3}-\mathrm{GO}$ nanocomposites prepared by a phase transfer method with long-term antibacterial property," ACS Applied Materials and Interfaces, vol. 5, no. 21, pp. 11307-11314, 2013. 
[6] P. Bober, J. Liu, K. S. Mikkonen et al., "Biocomposites of nanofibrillated cellulose, polypyrrole, and silver nanoparticles with electroconductive and antimicrobial properties," Biomacromolecules, vol. 15, no. 10, pp. 3655-3663, 2014.

[7] R. Kumar, S. Anandan, K. Hembram, and T. N. Rao, “Efficient $\mathrm{ZnO}$-based visible-light-driven photocatalyst for antibacterial applications," ACS Applied Materials \& Interfaces, vol. 6, no. 15, pp. 13138-13148, 2014.

[8] S. H. Hwang, J. Song, Y. Jung, O. Y. Kweon, H. Song, and J. Jang, "Electrospun $\mathrm{ZnO} / \mathrm{TiO}_{2}$ composite nanofibers as a bactericidal agent," Chemical Communications, vol. 47, no. 32, pp. 9164-9166, 2011.

[9] J. Manna, G. Begum, K. P. Kumar, S. Misra, and R. K. Rana, "Enabling antibacterial coating via bioinspired mineralization of nanostructured $\mathrm{ZnO}$ on fabrics under mild conditions," ACS Applied Materials and Interfaces, vol. 5, no. 10, pp. 4457-4463, 2013.

[10] M. Safarpour, A. Khataee, and V. Vatanpour, "Preparation of a Novel Polyvinylidene Fluoride (PVDF) ultrafiltration membrane modified with reduced graphene oxide/titanium dioxide $\left(\mathrm{TiO}_{2}\right)$ nanocomposite with enhanced hydrophilicity and antifouling properties," Industrial \& Engineering Chemistry Research, vol. 53, no. 34, pp. 13370-13382, 2014.

[11] I. Perelshtein, G. Applerot, N. Perkas, J. Grinblat, and A. Gedanken, "A one-step process for the antimicrobial finishing of textiles with crystalline $\mathrm{TiO}_{2}$ nanoparticles," Chemistry A: European Journal, vol. 18, no. 15, pp. 4575-4582, 2012.

[12] J. Xiong, Z. Li, J. Chen, S. Zhang, L. Wang, and S. Dou, "Facile synthesis of highly efficient one-dimensional plasmonic photocatalysts through Ag@ $\mathrm{Cu}_{2} \mathrm{O}$ core-shell heteronanowires," ACS Applied Materials \& Interfaces, vol. 6, no. 18, pp. 1571615725, 2014.

[13] X. Zhang, T. Zhang, J. Ng, and D. D. Sun, "High-performance multifunctional $\mathrm{TiO}_{2}$ nanowire ultrafiltration membrane with a hierarchical layer structure for water treatment," Advanced Functional Materials, vol. 19, no. 23, pp. 3731-3736, 2009.

[14] X. Wang, H.-F. Wu, Q. Kuang, R.-B. Huang, Z.-X. Xie, and L.-S. Zheng, "Shape-dependent antibacterial activities of $\mathrm{Ag}_{2} \mathrm{O}$ polyhedral particles," Langmuir, vol. 26, no. 4, pp. 2774-2778, 2010.

[15] A. Simon-Deckers, S. Loo, M. Mayne-L’Hermite et al., "Size-, composition- and shape-dependent toxicological impact of metal oxide nanoparticles and carbon nanotubes toward bacteria," Environmental Science and Technology, vol. 43, no. 21, pp. 8423-8429, 2009.

[16] H. Koga, T. Kitaoka, and H. Wariishi, "In situ synthesis of silver nanoparticles on zinc oxide whiskers incorporated in a paper matrix for antibacterial applications," Journal of Materials Chemistry, vol. 19, no. 15, pp. 2135-2140, 2009.

[17] M. Li, S. Pokhrel, X. Jin, L. Mädler, R. Damoiseaux, and E. M. V. Hoek, "Stability, bioavailability, and bacterial toxicity of Zno and iron-doped Zno nanoparticles in aquatic media," Environmental Science and Technology, vol. 45, no. 2, pp. 755761, 2011.

[18] S. Ghosh, V. S. Goudar, K. G. Padmalekha, S. V. Bhat, S. S. Indi, and H. N. Vasan, "ZnO/Ag nanohybrid: synthesis, characterization, synergistic antibacterial activity and its mechanism," RSC Advances, vol. 2, no. 3, pp. 930-940, 2012.

[19] Z. Huang, X. Zheng, D. Yan et al., "Toxicological effect of ZnO nanoparticles based on bacteria," Langmuir, vol. 24, no. 8, pp. 4140-4144, 2008.
[20] G. Applerot, J. Lellouche, N. Perkas, Y. Nitzan, A. Gedanken, and E. Banin, " $\mathrm{ZnO}$ nanoparticle-coated surfaces inhibit bacterial biofilm formation and increase antibiotic susceptibility," RSC Advances, vol. 2, no. 6, pp. 2314-2321, 2012.

[21] F. Gladis, A. Eggert, U. Karsten, and R. Schumann, "Prevention of biofilm growth on man-made surfaces: evaluation of antialgal activity of two biocides and photocatalytic nanoparticles," Biofouling, vol. 26, no. 1, pp. 89-101, 2010.

[22] B. M. Geilich and T. J. Webster, "Reduced adhesion of Staphylococcus aureus to $\mathrm{ZnO} / \mathrm{PVC}$ nanocomposites," International Journal of Nanomedicine, vol. 8, pp. 1177-1184, 2013.

[23] J. W. Rasmussen, E. Martinez, P. Louka, and D. G. Wingett, "Zinc oxide nanoparticles for selective destruction of tumor cells and potential for drug delivery applications," Expert Opinion on Drug Delivery, vol. 7, no. 9, pp. 1063-1077, 2010.

[24] M. J. Osmond and M. J. McCall, "Zinc oxide nanoparticles in modern sunscreens: an analysis of potential exposure and hazard," Nanotoxicology, vol. 4, no. 1, pp. 15-41, 2010.

[25] P. T. Sudheesh Kumar, V.-K. Lakshmanan, T. V. Anilkumar et al., "Flexible and microporous chitosan hydrogel/nano $\mathrm{ZnO}$ composite bandages for wound dressing: in vitro and in vivo evaluation," ACS Applied Materials and Interfaces, vol. 4, no. 5, pp. 2618-2629, 2012.

[26] M. Jensen-Waern, L. Melin, R. Lindberg, A. Johannisson, L. Petersson, and P. Wallgren, "Dietary zinc oxide in weaned pigs-effects on performance, tissue concentrations, morphology, neutrophil functions and faecal microflora," Research in Veterinary Science, vol. 64, no. 3, pp. 225-231, 1998.

[27] S. X. Huang, M. McFall, A. C. Cegielski, and R. N. Kirkwood, "Effect of dietary zinc supplementation on Escherichia coli septicemia in weaned pigs," Journal of Swine Health and Production, vol. 7, no. 3, pp. 109-111, 1999.

[28] R. Brayner, R. Ferrari-Iliou, N. Brivois, S. Djediat, M. F. Benedetti, and F. Fievet, "Toxicological impact studies based on Escherichia coli bacteria in ultrafine $\mathrm{ZnO}$ nanoparticles colloidal medium," Nano Letters, vol. 6, no. 4, pp. 866-870, 2006.

[29] L. Zhang, Y. Jiang, Y. Ding, M. Povey, and D. York, "Investigation into the antibacterial behaviour of suspensions of $\mathrm{ZnO}$ nanoparticles (ZnO nanofluids)," Journal of Nanoparticle Research, vol. 9, no. 3, pp. 479-489, 2007.

[30] X. Li, Y. Xing, Y. Jiang, Y. Ding, and W. Li, "Antimicrobial activities of $\mathrm{ZnO}$ powder-coated PVC film to inactivate food pathogens," International Journal of Food Science and Technology, vol. 44, no. 11, pp. 2161-2168, 2009.

[31] C. Karunakaran, V. Rajeswari, and P. Gomathisankar, "Antibacterial and photocatalytic activities of sonochemically prepared $\mathrm{ZnO}$ and Ag-ZnO," Journal of Alloys and Compounds, vol. 508, no. 2, pp. 587-591, 2010.

[32] N. Jones, B. Ray, K. T. Ranjit, and A. C. Manna, "Antibacterial activity of $\mathrm{ZnO}$ nanoparticle suspensions on a broad spectrum of microorganisms," FEMS Microbiology Letters, vol. 279, no. 1, pp. 71-76, 2008.

[33] I. Sondi and B. Salopek-Sondi, "Silver nanoparticles as antimicrobial agent: a case study on E. coli as a model for Gramnegative bacteria," Journal of Colloid and Interface Science, vol. 275, no. 1, pp. 177-182, 2004.

[34] G. Appierot, A. Lipovsky, R. Dror et al., "Enhanced antibacterial actiwity of nanocrystalline $\mathrm{ZnO}$ due to increased ROSmediated cell injury," Advanced Functional Materials, vol. 19, no. 6, pp. 842-852, 2009.

[35] A. Lipovsky, Z. Tzitrinovich, H. Friedmann, G. Applerot, A. Gedanken, and R. Lubart, "EPR study of visible light-induced 
ros generation by nanoparticles of ZnO," Journal of Physical Chemistry C, vol. 113, no. 36, pp. 15997-16001, 2009.

[36] L. K. Adams, D. Y. Lyon, and P. J. J. Alvarez, "Comparative ecotoxicity of nanoscale $\mathrm{TiO}_{2}, \mathrm{SiO}_{2}$, and $\mathrm{ZnO}$ water suspensions," Water Research, vol. 40, no. 19, pp. 3527-3532, 2006.

[37] W. Bai, Z. Zhang, W. Tian et al., "Toxicity of zinc oxide nanoparticles to zebrafish embryo: a physicochemical study of toxicity mechanism," Journal of Nanoparticle Research, vol. 12, no. 5, pp. 1645-1654, 2010.

[38] M. Li, L. Zhu, and D. Lin, "Toxicity of ZnO nanoparticles to Escherichia coli: mechanism and the influence of medium components," Environmental Science \& Technology, vol. 45, no. 5, pp. 1977-1983, 2011.

[39] G. Sengupta, H. S. Ahluwalia, S. Banerjee, and S. P. Sen, "Chemisorption of water vapor on zinc oxide," Journal of Colloid And Interface Science, vol. 69, no. 2, pp. 217-224, 1979.

[40] K. B. Hewett, L. C. Anderson, M. P. Rosynek, and J. H. Lunsford, "Formation of hydroxyl radicals from the reaction of water and oxygen over basic metal oxides," Journal of the American Chemical Society, vol. 118, no. 29, pp. 6992-6997, 1996.

[41] K. Vanheusden, C. H. Seager, W. L. Warren, D. R. Tallant, and J. A. Voigt, "Correlation between photoluminescence and oxygen vacancies in ZnO phosphors," Applied Physics Letters, vol. 68, no. 3, pp. 403-405, 1996. 

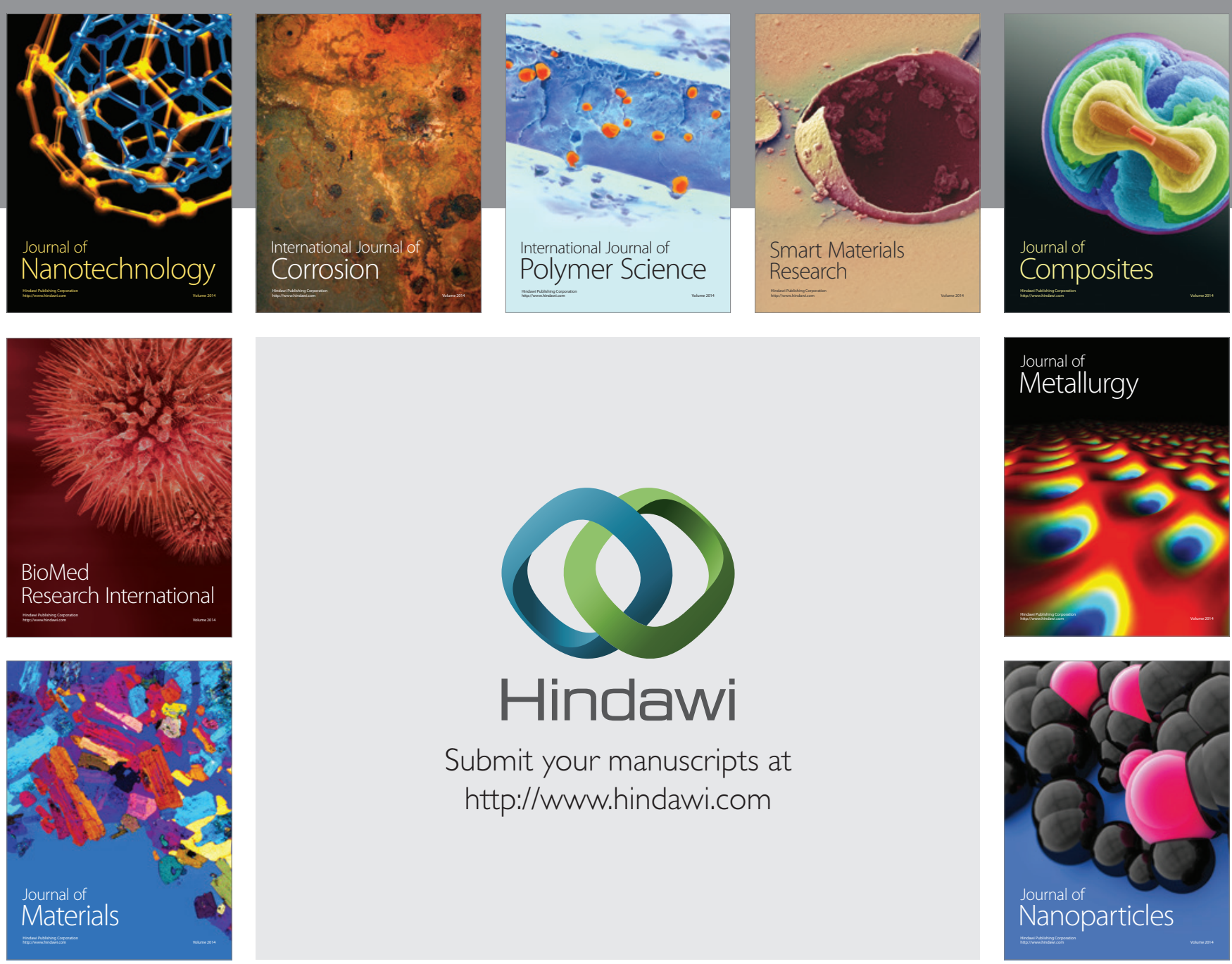

Submit your manuscripts at http://www.hindawi.com
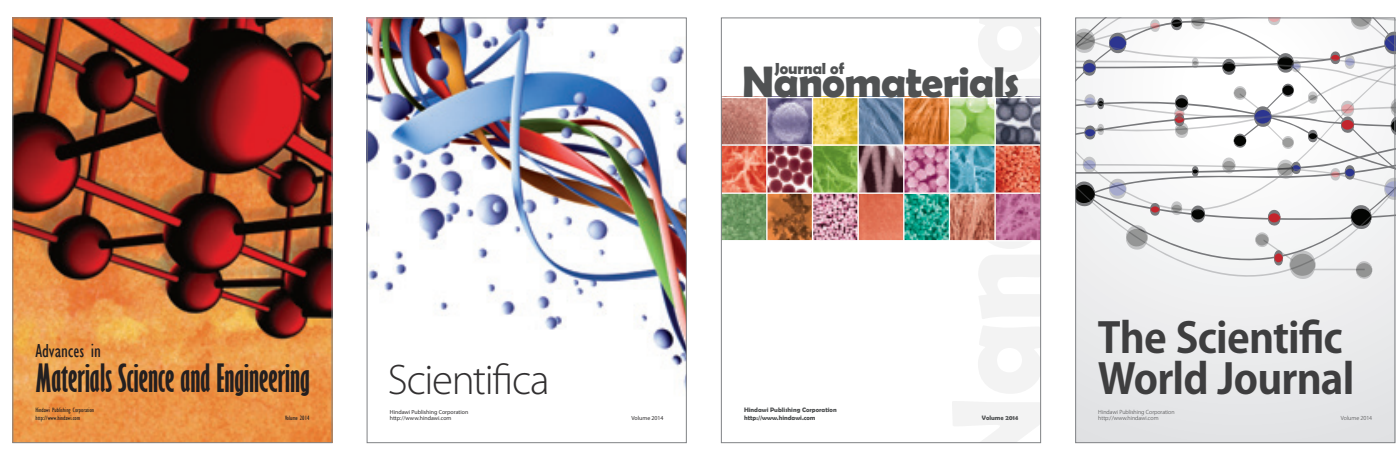

\section{The Scientific World Journal}
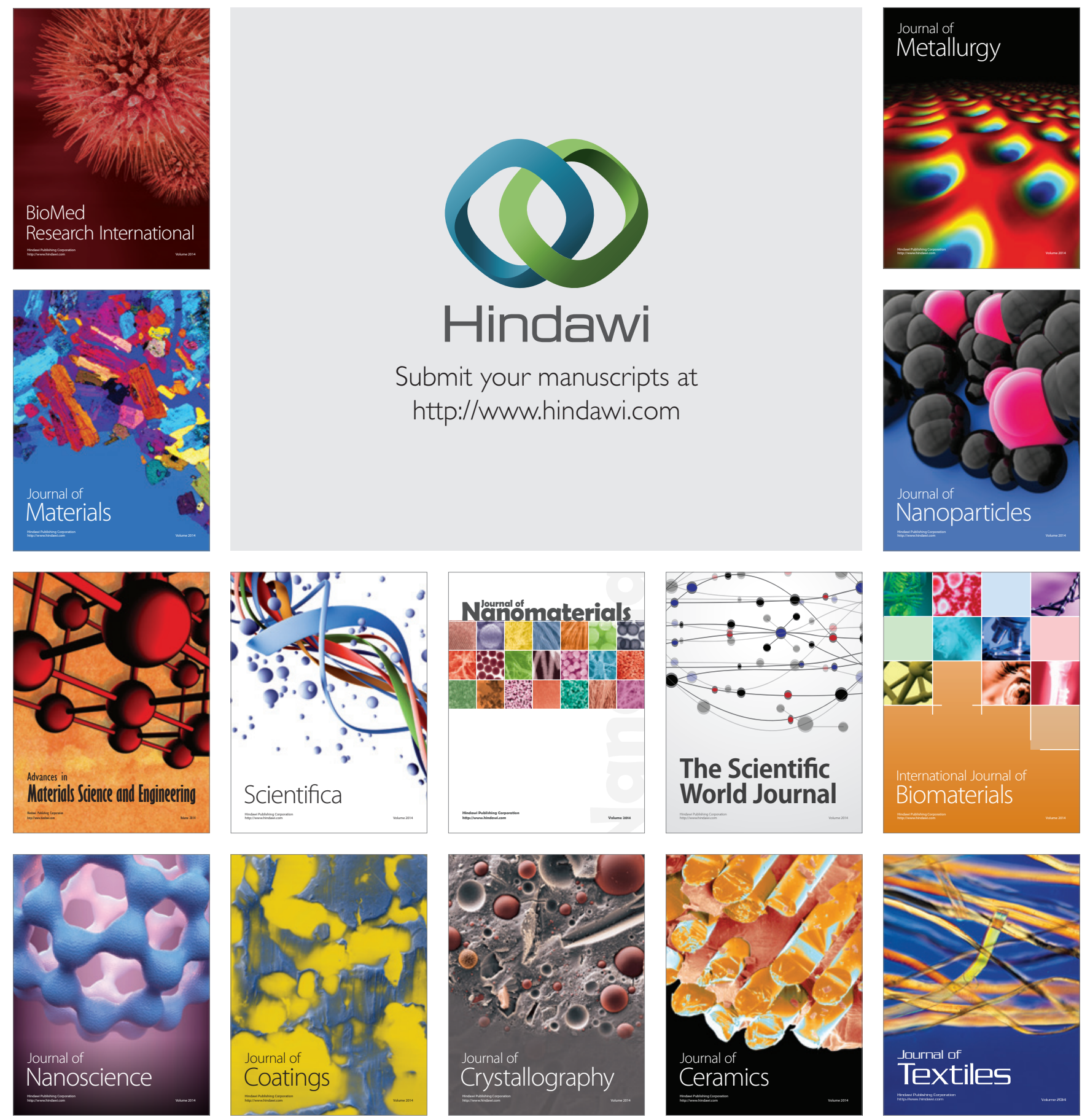